Copyright $@$ C 2021, Emerald Publishing Limited. This AAM is provided for your own personal use only. It may not be used for resale, reprinting, systematic distribution, emailing, or for any other commercial purpose without the permission of the publisher.

Acknowledgment: We are indebted to all the cantonal finance department senior budget officers who provided us with the necessary information to compute maturity levels, to the members of the Swiss Public Sector Financial Reporting Advisory Committee who took time to rank and compare the criteria to assess the convergence and to Michelle Bailat-Jones for her editing assistance.

\title{
On the road towards IPSAS with a maturity model: A Swiss case study
}

\author{
Nils Soguel and Naomi Luta - IDHEAP-Swiss graduate school of public \\ administration, Lausanne, Switzerland
}

This is the accepted version of the paper published as: https://doi.org/10.1108/IJPSM-092020-0235 in International Journal of Public Sector Management (IJPSM).

\begin{abstract}
Purpose - The International Public Sector Accounting Standards (IPSAS) have driven the modernisation of public systems of financial information. The extent and pace of their implementation remain uneven. The goal of this study was to measure whether and how much governmental accounting standards converge towards IPSASs' true and fair approach.

Design/Methodology/Approach - The empirical context of the 26 Swiss cantons was used to apply a simplified maturity model. Under two successive reforms (maturity stages), each canton's accounting standards were assessed and scored. The derived maturity levels indicate how close-or far-each canton has stood from a state of full IPSAS compliance (full maturity), at each stage of the process.
\end{abstract}

Findings - As Swiss cantons have a certain degree of autonomy in setting their own accounting standards, the evolving paths they followed when implementing IPSASs were heterogeneous. The maturity level attained by each canton within each stage thus varies. However, the results show that the two successive reforms had an overall favourable impact on Swiss cantonal accounting standards compliance with IPSAS, and fairly improved the faithfulness of reported financial information.

Originality - This research contributes to the international literature on public accounting standards and provides new insights for the assessment of convergence with IPSAS.

Keywords - Maturity model; Multicriteria decision analysis; Accounting standards; IPSAS; Convergence; Financial faithfulness; Swiss cantons.

\section{Introduction}

Many governments have implemented accounting reforms over the past forty years to respond more effectively to growing demands of financial accountability and reliability but also for decision-making purposes (Guthrie et al., 1999; Bergmann, 2012). The ongoing development of the International Public Sector Accounting Standards (IPSAS or IPSASs) since 1997 has driven forward this modernisation process. It has also provided public entities with a general framework for a harmonised application of accrual accounting principles. Simultaneously, IPSAS have set a yardstick against which to gauge how far the reforms go toward a faithful presentation of financial information. Indeed, there is no legal obligation for governments to adopt these international accounting standards unless their national legislation renders their implementation binding (IFAC, 2019). The incorporation of IPSAS into national or local regulations therefore remains flexible, leading to heterogeneous levels of compliance. Both the scope and content of accounting reforms are influenced by the institutional context and by a government's specific needs, beliefs and preferences (Pina and Torres, 2003; Christiaens et al., 2010). This means that how and when accounting standards are applied, and thus the degree of faithfulness of the financial information, is a constantly evolving and improving process.

The goal of this paper is to precisely measure whether and how much accounting standards converge towards IPSAS. Conceptually, the paper innovates by considering that compliance 
with these international standards is an evolving process often requiring not only a single reform, but several successive reforms. The concept of maturity model (MM) is well suited to this perspective since it formally defines various maturity stages and dimensions with which to measure overall maturity level. MM has hardly been applied to the field of financial management, and even less to public sector financial management, although it is increasingly applied in other management areas, especially in information systems, as an approach to organisational development, and as a means of organisational assessment (Mettler et al., 2010). For this study, MM is used for this latter purpose.

The procedure relies upon a multicriteria decision analysis technique called MACBETH (Bana e Costa et al., 2016) which requires only qualitative judgments to quantify the relative attractiveness of options (here, accounting practices). Our paper takes advantage of the Swiss empirical context to apply a simplified maturity model. The 26 Swiss cantons (the institutional equivalent of provinces or states in other countries) went through two successive major accounting reforms over the past forty years. Each time, the reform was triggered by an exterior entity, namely an intercantonal body. However, each Swiss canton constitutionally enjoys a high degree of autonomy when setting and applying accounting standards. This means that each canton was able to decide to what extent it would follow the external recommendations and when to implement them. These two reforms delineate two stages of maturity. The cantons all reached the first, then the second maturity stage at different times and, within each stage, demonstrated different maturity levels, i.e. alignment to IPSAS. Consequently, each canton followed its own road at its own pace under successive externally provided maturity guidelines.

Yet, maturity levels generally trended upward, suggesting that both reforms fostered the use of an increasingly sophisticated accrual accounting at the subnational level. It is thus a successful example of what happens when harmonised accounting standards are set at an upper level and lower tiers are then advised to reform their homegrown accounting systems accordingly, while given some kind of implementation margin. The Swiss case could thus inform the initiative to centrally design European public sector accounting standards (EPSAS) that EU country members would then have to implement.

The paper is organised as follows: The next (second) section offers a brief literature review looking first at the assessment of governmental accounting standards and then at the idea and development of maturity models. This allows us to articulate our research questions. The third section introduces the institutional context framing Switzerland's public financial management and accounting. Following that, section four details the methodology used to define the maturity stages and measure the maturity levels. The fifth section provides the results obtained through our empirical investigations in the Swiss cantons and the final section is devoted to our conclusions.

\section{Literature review}

\section{Measuring the harmonisation of accounting standards}

Various contributions have addressed the process organisations use to enhance the harmonisation (lesser diversity, greater homogeneity), or actually achieve standardisation (uniformity) of accounting policies at the international level (Tay and Parker, 1990). This evolution of heterogeneous public accounting standards towards a better homogeneity is also referred to as convergence (Qu and Zhang, 2010).

Several studies have assessed the accounting standards set by national or local governments following reforms which aim to shift towards a stricter application of accrual accounting. However, because there is no consistent analytical background for conducting empirical public sector accounting research (Bergmann et al., 2019), some authors used rough methods based on specific benchmarks that are not necessarily common or operable in other contexts 
(Christiaens, 1999), while others compared homegrown accounting models directly with IPSAS (Benito et al., 2007; Brusca et al., 2013; Christiaens et al., 2015). Indeed, this latter group has gradually become a consistent reference when assessing the international convergence of governmental accounting standards (Rossi et al., 2016). Nonetheless, many of these qualitative studies were descriptive, only pointing out convergences and divergences without any systematic quantitative measurement of the degree of IPSAS compliance (see e.g. Brusca and Martínez, 2016).

Originally, accounting harmonisation was quantitatively measured using an index of several accounting criteria and was intended to evaluate how accounting standards were practically applied in both national and international contexts (Van der Tas, 1988). Methodological extensions were then proposed (see e.g. Carvalho et al., 2007). Other studies have concentrated on the degree of financial disclosure arising from a government's accounting practices. Ingram's (1984) disclosure index, for instance, inspired several studies to measure harmonisation in the presentation of specific accounting elements in financial statements (see e.g. Stanley et al., 2008). However, national or local accounting requirements have been commonly used as a reference point. A few recent studies (Pina and Torres, 2003; Pina et al., 2009) applied index-based methods to evaluate public sector accounting harmonisation using IPSAS as a benchmark. Furthermore, most index-based studies usually implicitly assumed that the different index components, i.e. the criteria used for assessment, were equally important, therefore unweighted. Yet ignoring the potential differences in importance between criteria could affect the measurement's accuracy (Hassan and Marston, 2019). This issue drives our first research question:

RQ1: Are the criteria used to assess accounting standards of unequal importance? That is to say, does the impact they have on the faithfulness of the reported financial information differ? If so, this would mean that some accounting and financial reporting practices should be first improved so as to make larger gains toward maturity level and, consequently, toward IPSAS convergence.

\section{Maturity models}

Maturity models (MM) arose within the software industry in the 1970s. They have become an important tool for organisational improvement. They are valuable in terms of allowing an organisation to encapsulate its actual development level with respect to a state representing the ideal situation in which to achieve its objectives (Anderson and Jenssen, 2003). MM help to identify strengths and weaknesses compared to an external benchmark, thus providing a roadmap for improvement.

Various MM have been developed both in theory and in practice, mostly to sequence an organisation's path to full maturity and improve its processes. For instance, Harrington's model (1991) offers six consecutive maturity stages, starting with a state where a process is not yet assessed (1) and ending where the considered process is rated world-class and continues to improve (6). Wheeler's (1997) offers four stages: (1) state of chaos, (2) brink of chaos, (3) threshold state, (4) ideal state where the process is in control and customer expectations are met.

Existing maturity models have been criticized despite their popularity, or because of it. According to Röglinger et al., (2012), the majority of existing MM are built upon the practical experience of the researchers. Unsurprisingly, the models then lack a proper theoretical basis. Most provide limited guidance on the specific steps required to increase maturity levels. Cronemyr and Danielsson (2013) also lament the absence of criteria to help users determine a system's current maturity stage, making it difficult to track methodical progression to the next stage. Indeed, criticisms often note the lack of consideration for results. By ignoring the performance relationship, existing $\mathrm{MM}$ allow an organisation to 
move through sequential maturity stages without achieving any noticeable improvement in their business practices (Albliwi et al., 2015).

Despite these criticisms, MM have been widely applied to evaluate processes and to improve the quality and use of technical or managerial resources (e.g. IT digitalisation, information management, e-government) both in business and public administration (Mettler et al., 2010; Andersen and Henriksen, 2006). Campbell et al. (2012) appear to provide the unique example of MM applied to the finance function. The notion of "maturity" has been used in a public sector context (Frintrup et al., 2020) and attempts have been made to categorise the various forms of public accounting encountered (see Lande and Rocher, 2011). As far as we know, only PwC (2014) developed a structured framework to assess 'accounting maturity' in various EU Member States and Switzerland, according to the extent of their adoption of IPSAS. Accounting maturity - expressed in scores - was then used to provide an indication of the remaining efforts needed to ensure full compliance when implementing EPSASs. However, assessing accounting maturity at a single point in time precluded the exploitation of the temporal dimension (i.e. evolution over time) offered by a full-fledged MM. Furthermore, considering both central and local governments in the same study blurred results, since issues and challenges may differ between institutional levels. Jorge et al. (2016) followed a similar approach to test whether more maturity in implementing IPSAS improves the convergence between governmental accounting and national accounting and reduces the adjustments while translating data from the former to the latter.

The IPSAS reference system can legitimately be considered the stage of full maturity of an accounting and reporting system. Knowing this could then provide a top-down approach towards IPSAS. This approach would be mainly normative with an initial emphasis on what represents maturity and how to measure it (De Bruin et al., 2005). However, a bottom-up approach may be more adequate in the public sector, especially when jurisdictions, like Switzerland's cantons, have varying degrees of autonomy. This latter approach first defines the dimensions and characteristics representing maturity (Lahrmann et al., 2011). It allows the MM to incorporate observed diversity among organisations and non-linearity in the sequence of maturity stages, e.g. moves forward and backward, or skipped stages (Depaoli and Za, 2013; Mettler and Pinto, 2018). This leads to our second research question:

RQ2: In cases where jurisdictions have some degree of autonomy for deciding their accounting standards, can a significant diversity be observed among them? If so, we recommend a bottom-up approach where dimensions and characteristics of maturity are defined rather than a top-down approach prescribing what "maturity" represents at every stage.

\section{Public sector accounting reforms in the Swiss cantons}

In Switzerland's federalist structure, public finances and accounting policy matters are managed autonomously by the cantons. Concretely, each canton establishes its own Financial Management Act of Parliament(FMAP) defining its fiscal organisation and process, as well as the standards required for preparing and presenting its budget and financial statements.

This institutional setting has fostered the development of diversified accounting standards at the subnational level. For instance, in the mid-1960s, several cantons were already using accounting models inspired by the private sector and similar to accrual accounting, i.e. using an income statement and a statement of financial position. By contrast, other cantons continued to favour traditional cash accounting.

The cantons attempted a few times to coordinate their accounting policies, but without success. However, in the early 1970s, requirements for transparency, comparability and accountability became increasingly prominent in the public sector, notably influenced by the 'New Public Management' (NPM) movement. In 1977, the intercantonal Conference of 
Cantonal Finance Ministers (CFM) decided to design a first Harmonised Accounting Model (HAM1) and offer it to the cantons (CFM, 1981). The purpose of the CFM gathering is to discuss and coordinate the cantons on fiscal matters when necessary. It has no power to impose policy, only recommend. Therefore, the cantons were free to adopt HAM1 and, if so, to how much they would conform. The heart of HAM1 consisted of a detailed chart of accounts including a statement of financial performance and a statement of financial position. HAM1 thus enshrined accrual accounting and budgeting as the norm for all cantons. However, it included only basic guidance on recognition and measurement and very little on additional disclosure. Consequently, it allowed for hidden reserves and was minimally prescriptive concerning provisions or accrual/deferral of expenses and revenues. Cantonal sovereignty meant this first reform towards accounting standards harmonisation was a slow process. It took until the late-1990s for HAM1 to be fully implemented at the cantonal level. Furthermore, its application was quite varied.

Beginning in the mid-2000s, various pressures arose in both central and subcentral levels of government where a better knowledge of the cost of public goods and services provision was becoming essential. During this same period, IPSAS became available. International capital markets were also asking for financial statements to be prepared in a more standardised way. This context prompted the CFM to design an updated version of HAM1. The secondgeneration of the Harmonised Accounting Model (HAM2) was released in 2008 and is currently the standard (CFM, 2008). The revised chart of accounts remains central in HAM2. It works alongside 20 standards established as recommendations the cantons may adopt or not. These standards generally follow IPSAS's principle of true and fair accounting. They include all IPSAS presentation requirements and most of the recognition requirements. However, on some points these standards offer the cantons alternative and less stringent accounting policies. Compared to HAM1, HAM2 restricts the possibility of accumulating hidden reserves and requires more systematic accrual/deferral of expenses and revenues. However, it also openly offers some forms of political finessing when preparing the financial statements (Soguel, 2020). Hence by providing alternatives to a strictly aligned IPSAS version, the CFM issued a set of standards that was able to satisfy two broad categories of cantons with possibly competing goals: (a) the cantons that wish their financial statements to give a faithful representation of their financial condition; (b) the cantons that wish to follow a political and prudent approach in their financial management, at the expense sometimes of a sincere and regular presentation of their financial statements. By 2018, all cantons had introduced HAM2.

\section{Methodology Definition of maturity stages}

The methodology considers the two successive reforms-HAM1 and HAM2- as two maturity stages. HAM1 was already an improvement on the previous stage where some cantons prepared and presented cash-based financial reports. Generally, this early stage can be described as equivalent to Wheeler's (1997) state or brink of chaos. HAM1 corresponds to a modified accrual accounting (Lande and Rocher, 2011) where most tangible assets and certain provisions are recognised and where accrual/deferral of expenses and revenues are still only partial. HAM2 intends to strengthen the standards over HAM1, however in a flexible way, notably by allowing governments some possibilities for political finessing. After HAM2, the next stage would be a strict accrual accounting that would ensure full IPSAS compliance. This would then achieve Wheeler's ideal state (Figure 1). 


\section{Measurement of maturity levels}

All cantons incorporated HAM1 and then HAM2 into their own legislation, i.e. into their FMAP, at some point in time. However, they exercised their sovereignty to "shop around" within the proposed models in order to meet their own needs, often perpetuating their accounting and financial management practices. As a result, while all eventually reached the same maturity stage, the degree of maturity of their practices varies between cantons within each maturity stage.

Since HAM2 lists explicitly where alternatives are offered to cantons who would not follow the IPSAS, this list provides the necessary criteria to evaluate maturity level. Accordingly, these 15 assessment criteria measure the extent to which the accounting policies converge with IPSAS's true and fair approach. These alternatives were mainly introduced at the request of the cantons that had privileged traditional accounting policies under HAM1 (see Soguel and Luta, 2020). Table 1 presents the identified criteria ranked in decreasing order of importance.

A simple way to address RQ1 - does the importance of these criteria vary? — would be to score each criterion using a standard scale of 1 (not important) to 10 (very important), or to allocate percentages among the criteria, with the most important criterion allocated the larger percentage-points. However, these solutions are too rough and hasty to enable a thoughtful elicitation of weights.

Figure 1 - Four maturity stages (own elaboration)

Stage 4 - Strict accrual accounting fully complying with IPSAS (ideal state)

Stage 3 - HAM 2 flexible but unfinished full accrual accounting

Stage 2 - HAM 1 modified accrual accounting

Stage 1 - cash or modified cash accounting (state or brink of chaos)

Table 1 - Criteria for measuring the maturity level of Swiss cantons' accounting standards

\begin{tabular}{cl}
\hline Rank $\mathbf{n}^{\circ}$ & \multicolumn{1}{c}{ Criteria } \\
\hline 1 & Use of accrual rather than cash basis accounting principles \\
\hline 2 & Linear depreciation method, over useful life rather than degressive depreciation \\
\hline 3 & Absence of additional depreciation charges (i.e. no political finessing) \\
\hline 4 & Low threshold for accruals and deferrals of past or future revenues and charges \\
\hline 5 & Absence of annual performance smoothing, e.g. using rainy-day funds (i.e. no political finessing) \\
\hline 6 & Measurement of non-administrative assets at market value rather than at depreciated historical cost \\
\hline 7 & Accrual recognition of tax revenues \\
\hline 8 & Absence of pre-financing (i.e. no political finessing) \\
\hline 10 & Low threshold for the recognition of capital expenditures in the statement of financial position \\
\hline 11 & Start of depreciation as soon as the asset is available for use \\
\hline 12 & Measurement of administrative assets at market value rather than at depreciated historical cost \\
\hline 14 & Presentation of financial indicators \\
\hline 15 & Separate recognition of capital expenditures from the obtained grants to finance them \\
\hline Presentation of a cash flow statement in accordance with IPSAS (investing activities including yield-producing investments \\
\hline This criterion is not directly prescribed by IPSAS. It was formally introduced by HAM2 but was already applied by some cantons under HAM1.
\end{tabular}
It is considered for the maturity assessment since this practice contributes to the understandability of financial statements aimed at by IPSAS. 
Here, we relied on the MACBETH (Measuring Attractiveness by a Categorical Based Evaluation Technique) multiple criteria decision analysis technique developed by Bana e Costa et al. (2016). The technique involves a first ordinal ranking of the different criteria followed by a pairwise comparison of their importance. Indeed, combining these two stages makes the information consistent enough to achieve numerical evaluations that can be properly considered weights.

The ranking and comparison were obtained from the members of the Swiss Public Sector Financial Reporting Advisory Committee (SRS) in June 2019 and June 2020. As SRS members, these persons are highly knowledgeable of accounting standards and strongly aware of the impact of fulfilling each individual criterion on the reported financial performance and position of the Swiss cantons. They also have a technical view of the issue and no political interest. Each expert was interviewed individually and asked to classify the different criteria in decreasing order of importance (1st rank for the criterion of highest importance through 15th rank for the criterion of lowest importance), with equal rankings allowed [1]. Secondly, each expert was asked to state the difference in importance between each criterion and the one immediately ranked below, by means of the following verbal statements: "null", "very weak", "weak", "moderate", "strong", "very strong" or "extreme" difference in importance. Using the MACBETH algorithm, we then computed the weights they attributed to each criterion.

The data regarding HAM1 implementation in cantonal legislation were collected via a questionnaire sent directly to the 26 Cantonal Finance Department Senior Budget Officers in late 2018. This dataset had never actually been exhaustively gathered [2]. For the standards defined by the cantons under HAM2, information came from the SRS.

Various scaling formats were used for coding the different criteria (see Soguel and Luta, 2020). Scales were either dichotomous, discrete, or continuous. However, they were always bounded over a closed and increasing interval extending from 0 to 1 , i.e. from $0 \%$ to $100 \%$. For each criterion, a maximum value of 1 was attributed to a canton whose accounting policy was fully compliant with IPSAS, or 0 if totally opposed.

The resulting values were multiplied by the weights associated to each criterion. Maturity levels were then computed for each canton by summing up the 15 weighted values. A canton that defined its accounting standards in accordance with IPSAS obtained a level close to $100 \%$ (high degree of IPSAS compliance). A canton with a conservative approach of public finance management displayed a level closer to $0 \%$ (low degree of IPSAS compliance). This process was performed separately for both HAM1 and HAM2 reforms.

\section{Results}

\section{Scores per criterion}

Table 2 shows the coded cantonal scores for each criterion used to assess maturity levels under HAM1 and HAM2. Criteria are ranked in descending order according to the average weights computed, based on the answers collected during the interviews. Essentially, respondent views converged regarding both the standards that are crucial to ensure true and fair reporting and those that are less important. This provides an empirical answer to RQ1: when using criteria to assess accounting standards, one should definitely consider the possibility that they are of unequal importance, meaning that they affect the faithfulness of the reported financial information with varying degrees.

As for the score, a mean value close to 1.00 point (pt) indicates that most of the cantons applied the criterion in a way that is consistent with IPSAS. In turn, a mean value close to $0.00 \mathrm{pt}$ indicates that practices are far from what IPSAS recommend. Right away, it is interesting to compare the weights given to the criteria by SRS members with the scores. The comparison indicates that criteria considered important for true and fair financial reporting are not necessarily those that score highly. 
Table 2 - Weights of assessment criteria and Swiss cantons' coded scores under HAM1 and HAM2

\begin{tabular}{|c|c|c|c|c|c|}
\hline \multirow[b]{2}{*}{ Criteria } & \multirow[b]{2}{*}{ Weights } & \multicolumn{2}{|c|}{ Score HAM1 } & \multicolumn{2}{|c|}{ Score HAM2 } \\
\hline & & Mean & Median & Mean & Median \\
\hline $\begin{array}{l}\text { Use of accrual rather than cash basis accounting } \\
\text { principles }\end{array}$ & 11.03 & 1.00 & 1.00 & 1.00 & 1.00 \\
\hline $\begin{array}{l}\text { Linear depreciation method, over useful life rather } \\
\text { than degressive depreciation }\end{array}$ & 8.62 & 0.37 & 0.50 & 0.82 & 1.00 \\
\hline Absence of additional depreciation charges & 8.46 & 0.10 & 0.00 & 0.58 & 0.50 \\
\hline $\begin{array}{l}\text { Low threshold for accruals and deferrals of past or } \\
\text { future revenues and charges }\end{array}$ & 8.23 & 0.95 & 1.00 & 0.89 & 0.99 \\
\hline Absence of annual performance smoothing & 8.21 & 0.58 & 1.00 & 0.54 & 1.00 \\
\hline $\begin{array}{l}\text { Measurement of non-administrative assets at market } \\
\text { value rather than at depreciated historical cost }\end{array}$ & 7.42 & 0.54 & 0.75 & 0.83 & 1.00 \\
\hline Accrual recognition of tax revenues & 7.33 & 0.60 & 0.50 & 0.65 & 0.50 \\
\hline Absence of pre-financing & 7.21 & 0.40 & 0.33 & 0.40 & 0.00 \\
\hline $\begin{array}{l}\text { Low threshold for the recognition of capital } \\
\text { expenditures in the statement of financial position }\end{array}$ & 7.07 & 0.86 & 0.95 & 0.79 & 0.90 \\
\hline $\begin{array}{l}\text { Start of depreciation as soon as the asset is available } \\
\text { for use }\end{array}$ & 6.61 & 0.19 & 0.00 & 0.65 & 1.00 \\
\hline $\begin{array}{l}\text { Measurement of administrative assets at market } \\
\text { value rather than at depreciated historical cost }\end{array}$ & 4.42 & 0.00 & 0.00 & 0.08 & 0.00 \\
\hline Presentation of financial indicators & 4.33 & 0.88 & 1.00 & 1.00 & 1.00 \\
\hline $\begin{array}{l}\text { Separate recognition of capital expenditures from the } \\
\text { obtained grants to finance them }\end{array}$ & 4.12 & 0.15 & 0.00 & 0.19 & 0.00 \\
\hline $\begin{array}{l}\text { Separate recognition of plots of land from buildings } \\
\text { erected on them }\end{array}$ & 3.83 & 0.25 & 0.00 & 0.58 & 1.00 \\
\hline $\begin{array}{l}\text { Presentation of a cash flow statement in accordance } \\
\text { with IPSAS }\end{array}$ & 3.10 & 0.00 & 0.00 & 0.85 & 1.00 \\
\hline Total average of mean and median values & & 0.46 & 0.47 & 0.66 & 0.73 \\
\hline
\end{tabular}

The application of accrual rather than cash basis accounting principles criterion shows a maximum score of $1.00 \mathrm{pt}$ under both HAMs. Not surprising since the goal of each HAM was to increase the use of accrual accounting. Other related criteria display high scores in a range between 0.86 and 0.95 pts, under HAM1 already (low threshold for the recognition of capital expenditures in the statement of financial position, presentation of financial indicators, low threshold for accruals and deferrals of past or future revenues and charges). By contrast, the Swiss cantons performed much worse in four other cases with scores between 0.10 and 0.25 pts (absence of additional depreciation charges, separate recognition of capital expenditures from the obtained grants to finance them, start of depreciation as soon as the asset is available for use, separate recognition of plots of land from buildings erected on them). This indicates that most cantons stuck to traditional accounting policies in these matters when implementing HAM1 reform. Eventually, two criteria show a score of $0.00 \mathrm{pt}$ under the HAM1 reform (presentation of a cash flow statement in accordance with IPSAS, measurement of administrative assets at market value). HAM1 did not address these matters, while HAM2 presented corresponding recommendations.

The move from HAM1 to HAM2 increases the mean and median scores. Since the accounting standards recommended in HAM2 push toward IPSAS compliance, this overall improvement fits our expectations. In some areas, the evolution is especially apparent, as indicated by the large increase in scores for the presentation of a cash flow statement in accordance with IPSAS (0.00 to $0.85 \mathrm{pts})$, start of depreciation as soon as the asset is available for use (0.19 to 0.65 pts), linear depreciation method ( 0.37 to $0.82 \mathrm{pts})$ and measurement of nonadministrative assets at market value ( 0.54 to $0.83 \mathrm{pts})$. Otherwise, results are more mixed. For instance, the Swiss cantons are still a long way from IPSAS regarding their practices for the measurement of administrative assets at market value $(0.08 \mathrm{pts})$ or the separate recognition of capital expenditures from the obtained grants $(0.19 \mathrm{pts})$. In a few exceptional cases, cantons even slightly relaxed their standards with the second reform (low thresholds 
for the recognition of capital expenditures in the statement of financial position, recognition of accruals and deferrals of past or future revenues and charges and annual performance smoothing). Mean and median scores are consequently lower under HAM2. However, this relaxing remains overall marginal.

These results provide an empirical answer to RQ2: we observed a significant diversity in the accounting standards implemented when jurisdictions, such as Switzerland's cantons, had some degree of autonomy in this area. This consequently legitimizes a bottom-up approach where maturity stages do not prescribe what "maturity" represents at every stage and therefore allow for different levels of maturity within a given stage.

\section{Maturity levels under HAM1 and HAM2}

Given each canton's scores and each criterion's weight, Table 3 reports the maturity level individually achieved by cantons, both at the HAM1 and HAM2 stages. Cantons are ranked in decreasing order according to HAM2 maturity levels. A result close to $100 \%$ reflects a high level of compliance with IPSAS and accordingly of maturity. In turn, a result close to $0 \%$ indicates a low maturity level, as well as accounting and reporting practices that widely depart from the recommended accounting policies.

Results shows that the HAM1 reform already led the cantons towards a strict use of accrual accounting. Maturity levels lay in a range between $27.26 \%(\mathrm{SH})$ and $88.25 \%$ (GE). Only 15 cantons show maturity levels below $50 \%$, whereas 2 cantons are already above $80 \%$.

HAM2 reform brought the faithfulness of the financial information a step further. Maturity levels reach a range between $45.96 \%(\mathrm{OW})$ and $97.76 \%(\mathrm{ZH})$ [3]. Only 3 cantons remain below $50 \%$, while 6 cantons are above $80 \%$ and 3 even above $90 \%$. Alongside HAM2 implementation, IPSAS are referred to as the standards to be applied in most of the topscoring cantons' FMAP (ZH, GE, BS, LU).

Beyond these figures, there are glaring intercantonal disparities, as evidenced by the high standard deviations, both during HAM1 and HAM2 stages. Although cantons were twice given the opportunity to improve and harmonise their standards, their progress has not necessarily been equal. Obviously, accrual accounting is practiced in different ways by the cantons.

Table 3 also highlights disparities regarding when reforms were implemented. It took 22 years (1977 to 1999) for all cantons to introduce HAM1 and 10 years (2008 to 2018) for HAM2. The table also shows the cantons that implemented the reform within 5 years of the CFM release of HAM1 (i.e. until 1982) or HAM2 (i.e. until 2013), considered early bird cantons (EB). Others are considered latecomers (LC). The cantons that introduced HAM1 relatively quickly were also often those to first introduce HAM2, and likewise for latecomer cantons. On average, early bird cantons reached higher maturity levels than latecomers under both HAM1 $(+1.5$ percentage points, pp) and HAM2 (+4.3 pp). There seems then to be a positive correlation between moving early into a new maturity stage and the level of maturity attained within the stage.

\section{Characteristics of the evolutionary paths towards compliance with IPSAS}

Maturity levels generally trended upward, meaning cantonal accounting standards converged towards IPSAS over the two successive reforms. Accordingly, the faithfulness and transparency of reported information improved over time. Where the variation occurs, however, is in when cantons chose to move from one stage to the next (i.e. move to HAM1 and then to HAM2) and the maturity levels targeted within each stage. This suggests a diversity of paths towards possible full compliance with IPSAS.

Figure 2 introduces a distinction between three identified varieties of evolutionary paths (see Fuchs et al., 2017). The variety depicted in the left panel comprises the sharp mover cantons. 
These 13 cantons saw the benefit of moving into the third maturity stage with the release of HAM2. They have consistently drawn their accounting and reporting practices closer to IPSAS. As a result, the maturity level soared by +15 pp or more when shifting from HAM1 to HAM2. Admittedly, most cantons, which now closely comply with IPSAS, previously demonstrated levels of maturity below $50 \%$. The middle panel shows the moderate mover cantons. The maturity level in this group of 9 cantons has also increased, but to a lesser extent (between $0 \mathrm{pp}$ and $+15 \mathrm{pp}$ ). Five of them already showed levels above 50\% under HAM1. Finally, the right panel includes 4 steady cantons. In this group, Geneva (GE) is an exception since its maturity level was already very high under HAM1 (88.25\%). Furthermore, Geneva had already then among the highest scores meaning it had extremely limited room to further

Table 3 - Swiss cantons' maturity levels under HAM1 and HAM2

\begin{tabular}{|c|c|c|c|c|c|c|}
\hline \multirow[b]{2}{*}{ Canton } & \multicolumn{3}{|c|}{ HAM1 } & \multicolumn{3}{|c|}{ HAM2 } \\
\hline & $\begin{array}{c}\text { Maturity } \\
\text { level }\end{array}$ & $\begin{array}{c}\text { Time of } \\
\text { introduction }\end{array}$ & $\begin{array}{c}\text { Early bird or } \\
\text { Latecomer }\end{array}$ & $\begin{array}{c}\begin{array}{c}\text { Maturity } \\
\text { level }\end{array} \\
\end{array}$ & $\begin{array}{c}\text { Time of } \\
\text { introduction }\end{array}$ & $\begin{array}{c}\text { Early bird or } \\
\text { Latecomer }\end{array}$ \\
\hline Zürich (ZH) & 48.61 & 1982 & EB & 97.76 & 2009 & $\mathrm{~EB}$ \\
\hline Basel Stadt (BS) & 83.81 & 1999 & $\mathrm{LC}$ & 97.55 & 2013 & EB \\
\hline Lucerne (LU) & 55.34 & 1988 & $\mathrm{LC}$ & 97.52 & 2012 & $\mathrm{~EB}$ \\
\hline Solothurn (SO) & 67.98 & 1982 & EB & 87.61 & 2012 & EB \\
\hline Geneva (GE) & 88.25 & 1985 & $\mathrm{LC}$ & 87.37 & 2014 & $\mathrm{LC}$ \\
\hline Basel Land (BL) & 45.42 & 1981 & EB & 84.45 & 2010 & EB \\
\hline Graubünden (GR) & 49.37 & 1988 & $\mathrm{LC}$ & 78.20 & 2013 & EB \\
\hline Aargau (AG) & 48.17 & 1995 & $\mathrm{LC}$ & 76.77 & 2014 & $\mathrm{LC}$ \\
\hline Bern (BE) & 47.14 & 1989 & $\mathrm{LC}$ & 76.47 & 2017 & $\mathrm{LC}$ \\
\hline Neuchâtel (NE) & 66.76 & 1981 & EB & 72.17 & 2018 & $\mathrm{LC}$ \\
\hline Schwyz (SZ) & 49.27 & 1987 & $\mathrm{LC}$ & 72.05 & 2016 & $\mathrm{LC}$ \\
\hline Appenzell A. (AR) & 47.16 & 1978 & EB & 68.73 & 2014 & $\mathrm{LC}$ \\
\hline Schaffhausen (SH) & 27.26 & 1990 & $\mathrm{LC}$ & 65.20 & 2018 & $\mathrm{LC}$ \\
\hline Ticino (TI) & 56.38 & 1986 & $\mathrm{LC}$ & 63.72 & 2014 & $\mathrm{LC}$ \\
\hline Uri (UR) & 55.07 & 1984 & $\mathrm{LC}$ & 62.91 & 2012 & EB \\
\hline Thurgau (TG) & 41.49 & 1987 & $\mathrm{LC}$ & 62.40 & 2012 & EB \\
\hline Nidwalden (NW) & 46.71 & 1980 & EB & 60.54 & 2010 & EB \\
\hline Glarus (GL) & 34.98 & 1984 & $\mathrm{LC}$ & 59.19 & 2011 & EB \\
\hline Vaud (VD) & 50.31 & 1992 & $\mathrm{LC}$ & 57.26 & 2014 & $\mathrm{LC}$ \\
\hline Freiburg (FR) & 47.75 & 1996 & $\mathrm{LC}$ & 55.37 & 2011 & EB \\
\hline St. Gallen (SG) & 46.59 & 1997 & $\mathrm{LC}$ & 55.21 & 2014 & $\mathrm{LC}$ \\
\hline Jura (JU) & 54.57 & 1979 & EB & 54.26 & 2012 & EB \\
\hline Appenzell I. (AI) & 34.98 & 1979 & EB & 53.12 & 2015 & $\mathrm{LC}$ \\
\hline Valais (VS) & 52.22 & 1983 & $\mathrm{LC}$ & 48.62 & 2018 & $\mathrm{LC}$ \\
\hline Zug (ZG) & 60.04 & 1979 & EB & 46.55 & 2012 & EB \\
\hline Obwalden (OW) & 33.33 & 1986 & $\mathrm{LC}$ & 45.96 & 2012 & EB \\
\hline Min. & 27.26 & 1978 & & 45.96 & 2009 & \\
\hline Max. & 88.25 & 1999 & & 97.76 & 2018 & \\
\hline Mean & $\mathbf{5 1 . 5 0}$ & 1986 & & 68.73 & 2013 & \\
\hline Median & 48.94 & 1986 & & 64.46 & 2013 & \\
\hline Std. Dev. & 13.80 & 6 & & 15.90 & 3 & \\
\hline
\end{tabular}


Figure 2 - Swiss cantons' evolutionary paths towards a possible full compliance with IPSAS

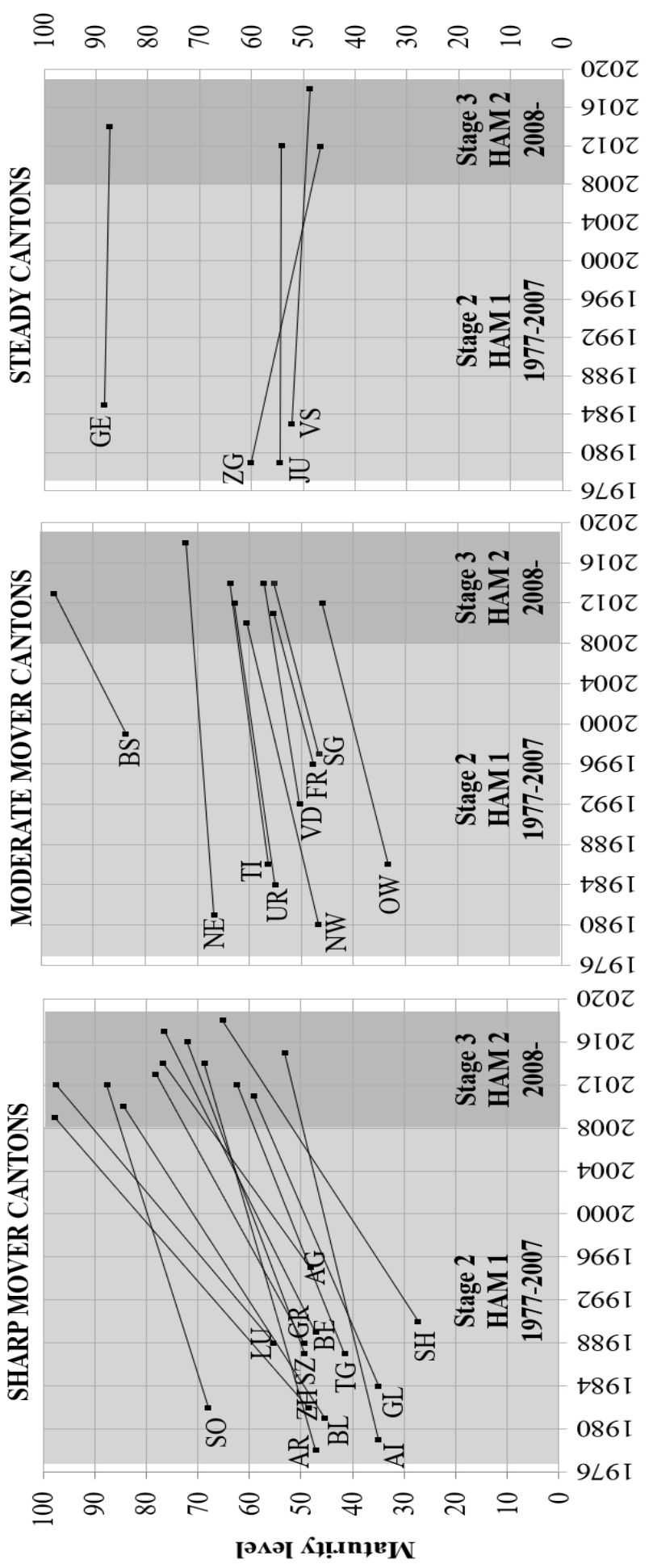


improve its practices. This is definitely not the case for the three other cantons in this group (ZG, JU, VS). With maturity levels between $50 \%$ and $60 \%$, they were in HAM1 mid-table. Despite the advent of HAM2, they decided not to seize the opportunity of this new maturity stage and maintained most of their standards while even sometimes relaxing others. They did not perceive the third stage of maturity brought by HAM2 as an opportunity to evolve their accounting and reporting practices. Also note that Obwalden (OW), although listed as a moderate mover, displays a lower maturity level than the steady cantons.

These results suggest that large cantons (e.g. ZH, GE) are keener to align their public sector accounting standards with IPSAS. The larger amounts of resources they manage, and the greater levels of indebtedness that often characterise them, may have prompted their compliance with well-known accounting standards for financial accountability purposes. In contrast, technical or administrative barriers may have prevented moderate movers and steady cantons from achieving a higher maturity level while implementing HAM2 and moving to the third maturity stage. Other, more political reasons may also explain why especially steady cantons deliberately maintained their existing — and comparatively lowmaturity level. Accordingly, these cantons could have sought to keep or even extend their accounting and financial reporting room to manoeuvre. Indeed, several moderate movers and all steady cantons (with the exception of Geneva) explicitly specified in their FMAP the possibility of practicing certain forms of political finessing (e.g. additional depreciation charges, annual performance smoothing, pre-financing).

\section{Conclusions}

Switzerland's federalism confers a high degree of autonomy to its subnational governments for setting their own standards when preparing and presenting their financial statements. Accordingly, this study used the empirical context of the 26 Swiss cantons to develop a simplified maturity model for assessing the level of convergence between their accounting standards and IPSASs' true and fair approach.

Twice in recent history, cantons received recommendations to change their accounting and reporting standards. These successive sets of recommendations delineate two maturity stages: a stage where accrual accounting, although modified, is recommended; followed by a stage where full accrual accounting is recommended, although in a flexible way. Within each stage, our study assesses the maturity level of the cantons' practices. The maturity level is measured according to 15 criteria aggregated using the MACBETH technique.

In response to our first research question, the empirical results - based on expert judgments provided by all members of the Swiss Public Sector Financial Reporting Advisory Committee - show that the unequal importance of the criteria should definitely be considered when appraising the ability of accounting and reporting standards to faithfully represent economic and other phenomenon. The most important criteria should logically be fulfilled as a first step toward attaining a faithful representation, yet the criteria prioritised by the different cantons for fulfilment were not necessarily those considered most important by the surveyed experts.

In response to our second research question, the results reveal a significant diversity in the accounting standards implemented when jurisdictions, such as the Swiss cantons, have some degree of autonomy in this area. The maturity level attained by each canton within each stage varies, although the two successive maturity stages implied by the succeeding sets of recommendations led to an increasing overall compliance of the Swiss cantons' accounting standards with IPSAS. Nevertheless, the evolutionary paths followed by the cantons through the maturity stages were highly heterogeneous. Three path "types" were identified. Half of the 26 cantons fall into the group called "sharp mover cantons". These governments took the opportunity of the release of the second set of recommendations to significantly increase the 
maturity level of their accounting and reporting practices. Consequently, these latter now closely comply with IPSAS. A third of the cantons falls into the "moderate movers" category. These cantons had already reached an acceptable maturity level following the first set of recommendations and then brought their practices slightly closer to IPSAS with the second reform. Eventually, only a handful of "steady cantons" decided not to seize the opportunity of this new maturity stage and kept most of their standards unchanged. These cantons probably maintained their existing - and comparatively low - maturity level in order to also maintain the possibility of practicing certain forms of political finessing.

A further set of recommendations leading to a third reform and a new maturity stage would probably be necessary for cantons to draw even closer to IPSAS and possibly fully comply with the international standards. However, the persistent heterogeneity in the definition of accounting standards and pace at which reforms have been adopted has demonstrated that some prudent cantons remain reluctant to change. Consequently, these might require more specific attention when defining the content of any forthcoming reform, to encourage efficiency and timeliness in their maturity process towards a full implementation of IPSAS.

This paper is one of the first to use a maturity model to assess the degree of IPSAS compliance at various stages in time. It is also the first to rely on a multiple criteria decision analysis technique and to use weighted criteria. From a research perspective, our methodology proves relevant for accurately assessing the evolution of financial information reporting and transparency in the public sector. It therefore offers a consistent method of measuring the dependent variable for future studies looking to identify the driving factors of heterogeneous governments' accounting standards and practices. Of course, the criteria used to assess maturity levels reflect the specificities of the Swiss accounting practices. This may lower the transferability of our results. However, future analyses could circumvent this limitation by assessing maturity levels according to criteria directly derived from the IPSAS. Policy-wise, this paper shows that even when governments remain free to adopt, or not, new sets of accounting standards as well as determine the extent of their conformity, time does its work. For sure there are early and late adopters, sharp and moderate movers, and also steady governments. However, these latter are a minority.

The Swiss cantons still have some distance to go. But after two major accounting reforms, the maturation process towards a full and sophisticated use of accrual accounting is unequivocally engaged. This incremental approach appears to be a success story since it has it both ways. The sovereignty of Switzerland's subnational governments in financial and accounting matters remains intact. Simultaneously, the use of accrual accounting is expanding at the cantonal level, thereby further strengthening the faithfulness of reported financial information.

This makes us cautiously optimistic if at some point European Public Sector Accounting Standards become a reality with member states granted flexibility in terms of implementation. Allowing a flexible implementation would certainly increase the chance of EPSAS being accepted. Flexibility, together with a few maturity stages, may lengthen the road but this is probably the price to be paid for a successful convergence towards a common set of standards.

\section{Notes}

1. The wording of the question was: "What is important to ensure a true and fair presentation of a government's financial situation (i.e. financial position and performance) in financial statements?" 
2. We would have liked to obtain information about cantonal accounting practices before the HAM1 reform, i.e. before the 1980s. Unfortunately, these data have never been surveyed. And the current serving officials were unable to provide this information.

3. Additional robustness checks were performed by comparing the obtained weighted values and maturity levels computed with equally weighted (i.e. unweighted) criteria. Maturity levels were found to be strongly correlated, but significantly different. The use of weighted or unweighted values does not much impact the overall picture of cantonal maturity levels but does influence the accuracy of measurement.

\section{References}

Albliwi, S. A., Antony, J., \& Arshed, N. (2015), “Critical literature review on maturity models for business process excellence", IEEE-International Conference on Industrial Engineering and Engineering Management, Wiley-IEEE Press, New Jersey, NJ, pp.79-83.

Andersen, K. V. and Henriksen, H. Z. (2006), "E-government maturity models: Extension of the Layne and Lee model", Government information quarterly, Vol. 23 No. 2, pp.236-248.

Anderson, E. S. and Jenssen, S. A. (2003), "Project maturity in organizations", International Journal of Project Management Accounting, Vol. 21 No. 6, pp.457-461.

Bana e Costa, C. A., De Corte, J. M., \& Vansnick, J. C. (2016), “On the mathematical foundations of MACBETH”, Greco, S., Ehrgott, M., \& Figueira, J. (Eds.), Multiple Criteria Decision Analysis, Springer, New York, NY, pp.421-463.

Benito, B., Brusca, I., \& Montesinos, V. (2007), "The harmonization of government financial information systems: the role of the IPSASs", International Review of Administrative Sciences, Vol.73 No.2, pp. 293-317.

Bergmann, A. (2012), "The influence of the nature of government accounting and reporting in decision-making: evidence from Switzerland", Public Money \& Management, Vol. 32 No. 1, pp.15-20.

Bergmann, A., Fuchs, S., \& Schuler, C. (2019), "A theoretical basis for public sector accrual accounting research: current state and perspectives", Public Money \& Management, Vol. 39 No.8, pp.560-570.

Brusca, I., Montesinos, V., \& Chow, D. S. (2013), "Legitimating international public sector accounting standards (IPSAS): the case of Spain", Public Money \& Management, Vol. 33 No. 6, pp.437-444.

Brusca, I., \& Martínez, J. C. (2016), “Adopting international public sector accounting standards: A challenge for modernizing and harmonizing public sector accounting", International Review of Administrative Sciences, Vol. 82 No. 4, pp.724-744.

Campbell, T., Fisher, J. G., \& Stuart, N. V. (2012), "Integrating sustainability with corporate strategy: A maturity model for the finance function", Journal of Corporate Accounting \& Finance, Vol. 23 No. 5, pp. 61-68.

Carvalho, J. B., Camões, P. J., Jorge, S. M., \& Fernandes, M. J. (2007), "Conformity and diversity of accounting and financial reporting practices in Portuguese local government", Canadian Journal of Administrative Sciences/Revue Canadienne des Sciences de l'Administration, Vol. 24 No. 1, pp.2-14.

CFM (Conference of Cantonal Finance Ministers/Konferenz der kantonalen Finanzdirektoren). (1981), Government accounting manual/Handbuch des Rechnungswesens der öffentlichen Haushalte [HAM1], Vol. 1-2, Verlag Paul Haupt, Bern (first published: 1977). 
CFM (Conference of Cantonal Finance Ministers/Konferenz der kantonalen Finanzdirektorinnen und Finanzdirektoren). (2008), Manual - Harmonised accounting model for cantons and municipalities/Handbuch - Harmonisiertes Rechnungsmodell für die Kantone und Gemeinden [HAM2], CFM, Bern.

Christiaens, J. (1999), "Financial accounting reform in Flemish municipalities: an empirical investigation", Financial Accountability \& Management, Vol. 15 No. 1, pp.21-40.

Christiaens, J., Reyniers, B., \& Rollé, C. (2010), "Impact of IPSAS on reforming governmental financial information systems: a comparative study", International Review of Administrative Sciences, Vol. 76 No. 3, pp.537-554.

Christiaens, J., Vanhee, C., Manes-Rossi, F., Aversano, N., \& Van Cauwenberge, P. (2015), "The effect of IPSAS on reforming governmental financial reporting: An international comparison", International Review of Administrative Sciences, Vol. 81 No. 1, pp.158-177.

Cronemyr, P. and Danielsson, M. (2013), "Process Management 1-2-3 - a maturity model and diagnostics tool", Total Quality Management \& Business Excellence, Vol. 24 No. 7-8, pp.933-944.

De Bruin, T., Rosemann, M., Freeze, R., \& Kaulkarni, U. (2005), "Understanding the main phases of developing a maturity assessment model", in Australasian Conference on Information Systems (ACIS), Australasian Chapter of the Association for Information Systems, pp.8-19.

Depaoli, P., and Za, S. (2013), “Towards the redesign of e-Business maturity models for SMEs”, in Baskerville, R., De Marco, M., \& Spagnoletti, P. (Eds.), Designing Organizational System: An interdisciplinary discourse, Springer, Berlin, Heidelberg, pp.285300 .

Frintrup, M., Schmidthuber, L., \& Hilgers, D. (2020), "Towards accounting harmonization in Europe: a multinational survey among budget experts", International Review of Administrative Sciences, pp.1-21.

Fuchs, S., Bergmann, A., \& Brusca, I. (2017), "Using Financial Reporting for Decision Making as a Measure Towards Resilient Government Finances: The Case of Switzerland", Lex localis-Journal of Local Self-Government, Vol. 15 No. 1, pp.133-153.

Guthrie, J., Olson \& Humphrey, C. (1999), "Debating developments in new public financial management: the limits of global theorizing and some new ways forward", Financial Accountability \& Management, Vol. 15 No. 3-4, pp.209-228.

Harrington, H. J. (1991), Business process improvement, McGraw-Hill, New York, NY.

Hassan, O. A. and Marston, C. (2019), "Disclosure Measurement in the Empirical Accounting Literature-A Review Article", International Journal of Accounting, Vol. 54 No.2, pp.1-58.

IFAC (International Federation of Accountants). (2019), Handbook of International Public Sector Accounting Pronouncements. IFAC, New York, NY.

Ingram, R. W. (1984), "Economic Incentives and the Choice of the State Government Accounting Practices", Journal of Accounting Research, Vol. 22 No. 1, pp.126-144.

Jorge, S. M., Jesus, M. A., \& Laureano, R. M. (2016), “Governmental accounting maturity toward IPSASs and the approximation to national accounts in the European Union", International Journal of Public Administration, Vol. 39 No.12, pp.976-988. 
Lahrmann, G., Marx, F., Mettler, T., Winter, R., \& Wortmann, F. (2011), "Inductive Design of Maturity Models: Applying the Rasch Algorithm for Design Science Research", in Hemant, J., Atish, P.S., \& Padmal, V. (Eds.), Service-Oriented Perspectives in Design Science Research, Springer, Milwaukee, WI, pp.176-191.

Lande, E. and Rocher, S. (2011), "Prerequisites for applying accrual accounting in the public sector", Public Money \& Management, Vol. 31 No. 3, pp.219-222.

Mettler, T., Rohner, P., \& Winter, R. (2010), "Towards a classification of maturity models in information systems", in D'Atri, A., De Marco, M., Braccini, A.M., \& Cabbidu, F. (Eds.), Management of the interconnected world, Physica-Verlag HD, Heidelberg, pp.333340 .

Mettler, T. and Pinto, R. (2018), "Evolutionary paths and influencing factors towards digital maturity: An analysis of the status quo in Swiss hospitals", Technological Forecasting and Social Change, Vol. 133, pp.104-117.

Pina, V. and Torres, L. (2003), "Reshaping public sector accounting: an international comparative view", Canadian Journal of Administrative Sciences/Revue Canadienne des Sciences de l'Administration, Vol. 20 No. 4, pp.334-350.

Pina, V., Torres, L., \& Yetano, A. (2009), “Accrual accounting in EU local governments: One method, several approaches”, European Accounting Review, Vol.18 No. 4, pp.765-807.

PricewaterhouseCoopers (PwC). (2014), "Collection of information related to the potential impact, including costs, of implementing accrual accounting in the public sector and technical analysis of the suitability of individual IPSAS standards", Brussels, Belgium, available at: https://ec.europa.eu/eurostat/documents/1015035/4261806/EPSAS-study-finalPwC-report.pdf (accessed 06 November 2020).

$\mathrm{Qu}, \mathrm{X}$. and Zhang, G. (2010), "Measuring the convergence of national accounting standards with international financial reporting standards: The application of fuzzy clustering analysis", The International Journal of Accounting, Vol. 45 No. 3, pp.334-355.

Röglinger, M., Pöppelbuss, J., \& Becker, J. (2012), "Maturity models in business process management”, Business Process Management Journal, Vol. 18 No. 2, pp.328-346.

Rossi, F. M., Cohen, S., Caperchione, E., \& Brusca, I. (2016), "Harmonizing public sector accounting in Europe: thinking out of the box", Public Money \& Management, Vol. 36 No.3, 189-196.

Soguel, N. (2020), Comprendre et gérer les finances de ma collectivité, EPFL Press, Lausanne.

Soguel, N. \& Luta, N. (2020), "Assessing How Much Governmental Accounting Standards Converge with IPSAS: A new methodology applied to Switzerland", Working Paper de l'IDHEAP 1/2020, IDHEAP, Lausanne.

Stanley, T., Jennings, N., \& Mack, J. (2008), "An examination of the content of community financial reports in Queensland local government authorities", Financial accountability \& management, Vol. 24 No. 4, pp. 411-438.

Tay, J. S. and Parker, R. H. (1990), "Measuring international harmonization and standardization", Abacus, Vol. 26 No. 1, pp.71-88.

Van der Tas, L. G. (1988), "Measuring harmonisation of financial reporting practice", Accounting and business research, Vol. 18 No. 70, pp.157-169.

Wheeler, D. J. (1997), “The four possibilities for any process”, Quality Digest, Vol. 17, pp.21-22.

Corresponding author: Nils Soguel: nils.soguel@unil.ch 